\title{
Incongruous liaisons: Routes of humour, insult and political (in)correctness in Nigerian stand-up jokes
}

\author{
Izuu Nwankwo E. \\ Chukwuemeka Odumegwu Ojukwu University, Igbariam, Nigeria \\ Wallenberg Centre, Stellenbosch, South Africa \\ izuunwankwo@gmail.com
}

\begin{abstract}
Nigerian humourists have always told risible jokes within myriad pre-colonial satirical acts. Following on their heels in recent times, stand-up comedy has emerged as one of the most prevalent art forms in the country, providing entertainment through laughter-eliciting jokes. Accompanying this development also, is an increasing attitude of offence-taking which has seen post-mortem criticisms and castigation of comedians. Not much scholarly attention has been paid to this menacing backlash against ostensible "inappropriate jokes" and the fact that stand-up humour is primarily derived from causing offence. What happens is that joke performances take place within liminal moments, which allows for audience's suspension of offence and the performer's unwritten consent to stay within socially accepted bounds of good humour. Through performance analysis, this paper sets out to study how four randomly selected Nigerian comics -I Go Dye, Basket Mouth, Klint da Drunk and AY-deploy selfcensorship in averting offence within their joke routines. The essay finds that despite the specificities of stand-up arts, which place peculiar demands on artists' joking capabilities especially in its dependence on courting audiences' participation and familiarity, these comedians have devised specific means through which they circumvent the stringency of eliciting mirth through insult. Hence, their jokes and those of others who have learned their trade well, often elicits hilarity rather than offence.
\end{abstract}

Keywords: humour, insult, Nigerian stand-up comedy, jokes, political correctness.

\section{The joke and its emergence offence}

With the global rise in sensibilities over race, religion, sexual orientation, and gender, people are becoming increasingly irritated by humour. From the condemnation of US comedian Daniel Tosh and his Nigerian counterpart Basket Mouth over "careless" remarks on rape; and the serial imprisonment of the Cameroonian-French Dieudonné over anti-Semitic remarks; the stride against comedy has escalated to cartoons turning deadly. The most compelling case is the various drawings of Prophet Muhammad that, in 2006, sparked riots in several Muslim countries; as well as the obvious and subdued religious intolerance that, in 2015, led to the 
attack on Paris-based Charlie Hebdo. These incidents underscore the fact that seriousness has crept into ordinarily jocular conditions within communities wherein voluntary suspension of offence is required. The basis of these liminal moments is described by Radcliffe-Brown (1940) as "joking relationship." For him, this relation exists "between two persons in which one is by custom permitted, and in some instances required, to tease or make fun of the other, who in turn is required to take no offence" (Radcliffe-Brown 1940: 195). He further avers:

The joking relationship is a peculiar combination of friendliness and antagonism. The behaviour is such that in any other social context it would express and arouse hostility; but it is not meant seriously and must not be taken seriously. There is a pretence of hostility and a real friendliness. To put it in another way, the relationship is one of permitted disrespect.

(Radcliffe-Brown 1940: 196)

Incidentally, the "permission" for periodic disrespect of institutions, persons, mannerisms, and the likes for the purpose of comedy seems to have been suspended by the deliberate and persistent calls for censorship of humourists and their art. Comedic insult has thus adorned its biting "sting" all over again to become slanderous and unacceptable, thereby putting the art of humour making and the artists themselves at risk.

What Radcliffe-Brown dubs "combination of friendliness and antagonism", also referred to as "negative ecstasy" (Nilsen 2001: 424) and "discovering similarities between dissimilars" (Freud 2002: 5), is instructive of the quagmire comedians are often confronted with in their trade. These paradoxical mixes underscore the inherent attraction and repulsion, something Hazlitt (1819: 23) says is made up of covert likenesses between opposites that become elaborate as absurdities and "sets off the quality we laugh at or despise in a still more contemptible or striking point of view". Specifically, it is within the intermix of amusement and repudiation that the comedian can extract humour, and this is not recent at all because humourists from different pre-Western civilization times exploited such strategies. In precolonial times, in parts of West Africa, especially Nigeria, there were comedic performances and observances within most of its over 250 ethnic groups. In the south east, among the Igbospeaking communities, njakịị ("jesting") and iko-onu ("exchange of insults") existed as joketelling games where participants showed prowess at stirring laughter using real, exaggerated, and overtly contrived stories about their opponents. The major difference is that in iko-onu, stories are mostly true but can also be hyperbolised or twisted out of proportion. There are two forms of this, however: one is serious and employed by individuals or parties as verbal fights; the other is more jocular and has more affinity with njakiri, where stories are mostly fabricated. Much of the tales deployed in iko-onu are real stories gleaned from gossips, repeated with the intention to hurt the opponent, while in njakiri one usually sees an exchange of insults between adult friends in jest where each participant invents spurious tales to score points against opponents. Meek (1937: 230) highlights the playful and friendly nature of these interactions by reporting that "one may often see two Igbo reviling each other in the strongest language for several minutes and then bursting into laughter as they walk away".

In the north of Nigeria, among the mainly Hausa-Fulani tribes, Wawan Sarki ("king's jester") developed specifically around ancient Zaria Emirate as individuals with "sanctioned verbal licence within the environment of a traditional court", and the 'yan kama (literally, "the catcher"), as "burlesque artists [who] perform in groups of two or three for money in markets and at social gatherings" (Furniss 1996: 96). Wawan sarki is further described as "the fool that makes the difference - difference in the sense that he occupies intractable place in society's scheme for ensuring a balance of power between the ruler and the ruled" (Kofoworola 2007: 105). He is thus the go-between for the king and his subjects using diverse comedic styles: "slapstick, parody and satiric burlesque" with the intention to "communicate serious messages in the form of jokes without creating any form of embarrassment" (Kofoworola 2007: 105). 
The 'yan kama (dan kama, singular), on the other hand, performed for the public in market places as entertainers. As a result, they were closer to most of the people than the king's jester who performed mainly in the palace for courtiers and commoners with special access to the Emir's court.

In the south west, among the Yoruba-speaking people, efe, enacted by the popular Gelede masked performers during traditional festivals mostly as songs, "is apparent in numerous songs ridiculing or mocking foolish or antisocial behaviour" (Lawal 1996: 38). Within this efe, "the traditional artist gets a day off from seriousness and rationality and is empowered by the community to ridicule all forms of rules, individuals high and low, gods and systems" (Obafemi 1996: 56). There were no no-go areas as performers satirised anything, they can think of within these moments that the society and its princes allow themselves to be ridiculed in a manner akin to the Medieval Feast of Fools which Bakhtin (1968) aptly codifies with the coinage carnivalesque. ${ }^{1}$ For the clowns, singers and performers of these comedic forms, their major duty is to

seize the nettle of humanity's inability to devise a painless way of organising itself by making it laugh at its own absurdity and defusing its pain, at least temporarily, by the creation of an alternative reality, one whose obvious unreality detracts from the personal relevance of the subject matter it presents.

(Grainger 2010: 23; my emphasis)

Grainger in this statement captures the entire gamut of how comedians in both present and ancient times deploy techniques that help them in keeping offence off-limits to their audiences. Joke situations are thus imbued with "a humbling tirade [...and] a ticklish outcome in view" even when they can land "a punitive punch on its target object(s)" (Nwachukwu-Agbada 2007: 154). The devices identified by Nwachukwu-Agbada (2004) as belonging to njakiri can be said to be tools exploited by comedians from time immemorial: "mockery, noisy laughter, raillery, parody, exaggeration and understatement of image"; and it is in the manner that these "rhetorical modes" are applied that one can have any/all of "obvious insult [...], downright abuse [...] or a quizzical play" (Nwachukwu-Agbada 2004: 153). Merely putting these tools together does not elicit laughter, nor does it make one a comedian. Making people laugh, especially within stand-up comedy, is challenging, tasking, and requires a great amount of intelligence and hard work.

\section{Stand-up humour and its unique challenges}

There are several challenges in artistic humour making but four are mostly unique to stand-up comedy. In the first instance, making people laugh is a trait stand-up shares with most comedic forms but, unlike the others forms, humour in stand-up comedy is the sole target and audience feedback is immediate and final. Hence, its accomplishment or otherwise is predicated on the level of mirth aroused by a performer. This means that whether teaching morals, instructing people on civic duties, and/or trying to do one social good or the other very successfully, once the comedian fails to create laughter, the effort is futile so long as audience satisfaction is concerned. Also, because audience response is instantaneous unlike in no other, comedians get to know in real-time how well their jokes are doing based on the way the audience laughs. Limon (2000: 11), in his three-fold theorising of the centrality of the audience in stand-up art, posits that an individual audience member's reservation is not regarded as important; there is

${ }^{1}$ Carnivalesque refers to the Medieval Feast of Fools in Europe, a folk humour that allowed the commoners to ridicule the church, its practices and priests. This process allows the church authority to decipher ways in which they are indulging in excesses and as such may end up taking steps towards addressing them. 
no room for recanting laughter already expressed; and stand-up comedy is the only art that relies on audience appreciation rather than on criticism to make its mark. He further avers:

laughter at a stand-up routine signifies that the joke is funny, and the joke cannot be funny without it. A joke at which the audience smiles or nods its approbation is a failed joke; a joke at which the audience laughs is a good joke in proportion to its laughter.

(Limon 2000: 12)

Thus, the importance of the audience and the immediacy of its assessment of stand-up routines are highlighted. For the novelist, painter, sculptor, musician, theatre actor, poet, and virtually every other artist, the critic is a central figure whose evaluation holds a major stake in the acceptance or rejection of what has been presented but for the stand-up artist, Limon conceives that judgment is not deferred because the audience is there to do just that in realtime. Post-mortem criticism of any sort whether delayed or otherwise is not necessary because: "To criticise a joke is to miss it, because the joke, as Freud demonstrates, is, in the first instance an escape from criticism to a prior happiness" (Limon 2000: 12). This accentuates the fact that even when an individual who does not understand a particular joke or feels offended by it hesitates, once it is told with the necessary laugh-inducing techniques and the majority responds with laughter, the later group's action endorses the risibility of the narrative and thus drowns every opposing view in that instant. For the fact that stand-up comedy is primarily live, this is all that is needed to consider the joke a success. The comedian's first challenge, therefore, is to be in tune with the audience by creating the commensurate friendliness and familiarity that his/her jokes require.

The second peculiar task confronting the comedian is that stand-up comedy catalyses mirth through its very opposite-causation of offence; no other art form makes this sort of seemingly counter-productive demand on the artist. Specifically, the humourist's art is further complicated by the fact that every successful joke must, by definition, abuse someone or something (in)directly. Surprisingly, it is also expected that the persons thus ridiculed or people like them, should find the affront humorous. Indubitably, obvious insult and outright abuse can be intolerable but within the permissiveness of joke situations, it is the responsibility of the joker to craft them into veritable comedic tools for the stimulation of hilarity. This is basically achieved by inveigling the audience into being receptive of the undesired-a condition described by Limon (2000: 4) as eliciting laughter by "way of avowing and disavowing abjection". It thus will appear that comedians are being sabotaged by the very purpose of their trade - creating amusement out of insult, abuse, and ridicule. Unlike the poet, for instance, who entertains with the beauty of words or the novelist who comes with narrative dexterity, the stand-up artist is expected to arouse the audiences' follies in beautiful invectives, garnished obscenities, ornate ridicule and still mysteriously make them laugh at their undersides with gratitude to the comedian. Indeed, it is not enough that they must be made to laugh even when the jokes are at their expense but, as has been noted above, it is this same audience being reviled by the performer that will ultimately evaluate the performance itself through the medium of giving or withholding laughter.

The third quandary is the directness of stand-up art. Humour artists speak with a high level of conviction required to create believability (and then laughter), which in turn, is misunderstood by the audience who sometimes take such expressions to be the personal views of individual comedians. Except in recorded versions of live shows, stand-up performers have little or no insulation from their presentations like some of their colleagues in other genres. Tafoya (2009: 18) makes a valid observation about how (in)direct other genres of art can be in relation to the readers/spectators: 
The poem, short story and novel must be transmitted through the written or spoken word, in situations where bright lines persist between the author and the narrator and the real and imagined audience. With stand-up comedy, however, the [performer] usually talks in his [or her] real voice, wears clothes that can hardly be called 'a costume' and addresses his [or her] audience directly and immediately. He [or she] can interrupt his [or her] own performance, change directions, return to an earlier sequence, add a comment here and subtract or condense a joke there. (Emphasis added.)

These thoughts rightly summarise the state of performer-audience relations within standup comedy: humourists' extensive use of imitation is not on the same pedestal as that of other stage actors. Theirs requires a "convincingness" needful to increase believability and enhance the stimulation of laughter. Ajaye (2002: 12) calls it "Honesty", which means that comedians must make their stories sound true - not that they cannot make them up. His advice on how this "honesty" can be achieved is instructive: "Don't try to give a funny opinion; give your opinion in a way that will be funny [...] and describe what you honestly see or feel" (Ajaye 2002: 12). Incidentally, it is the effort exerted towards the attainment of "honesty" in joke narration that audiences often misread and this is a great challenge because it is one of the key ingredients of stand-up comedy that stage performers cannot do without in the bid to elicit laughter in their audiences. Writers can create characters who hold extreme views, painters and musicians can broach taboo subjects in diverse ways and yet be insulated by their nonpresence in their narratives, but comedians do not enjoy this device. They are not only present but must reinforce their stage presence to gain and hold audience attention. They also do not merely tell stories for entertainment like the ancient raconteurs but must necessarily stir laughter in their audience.

The fourth very essential burden stand-up places on its exponents is spontaneity. Theatre actors are closest to jesters in terms of liveness of their art and the use of improvisation, but the immediacy and directness of comedians' art require spur-of-the-moment alterations and crafting. Tafoya (2009:18) puts it more succinctly: "[stand-up] performances can be molded, remolded and reremolded in the course of a single evening. A performer can exploit the art form's plasticity to fit each venue, each audience and even individual audience members". This assertion accentuates the fact that, within an event, there is a preponderance of off-script additions for the comedian being that some responses are meant specifically for reactions gleaned from the audience in the course of the performance. From the structure of a typical stand-up joke, once the punchline is given, there is still room for a tagline which is expected to lead to a series of other punchlines till the comedian has exhausted all jocular possibilities of that single narrative. The taglines are often altered by timing, inflection, and sometimes even content in order to make sure that whatever comes afterwards is tailor-made for that particular audience. Comedians do not just throw words in and hope either one or all of them attains the purpose; their diction, mode and rate of delivery are consciously selected for specific ends; and the choices already made are not final because they can be altered or completely truncated for entirely new ones in accordance with on-the-spot reading of spectator response. Stand-up comedy is one art form where pauses achieve much and are part of the central performance techniques for the delivery and exploitation of the loudest laugh possible in any joke narrative. Consequently, stand-up comedians are not involved in the creation of pre-planned, wellordered, articulated, and complete finished product like most of their fellow artists, they are rather part of the event, altering, and tweaking their work as it progresses, until the audience gives its verdict - giving or withholding of laughter, which is the completion of their art. 


\section{Understanding incongruous liaisons in Nigerian stand-up comedy}

Three major theories of humour have been identified: Incongruity, Superiority, and Relief theories of humour. The first two, however, are most relevant to this study. Incongruity theory, described as importing "into one situation what belongs to another" (Monro 1951: 45), designates much of what jocular humour stands for: that laughter is derived from two unlikely situations presented simultaneously, with an underlying shift in meaning which catches the audience by surprise because the resolution ends differently from the expectation of the recipients. Superiority theory of humour is best described by Raskin (1985: 36):

[it] is nothing else but sudden glory arising from some sudden conception of some eminency in ourselves, by comparison with the infirmity of others, or with our own formerly: for men (sic) laugh at the follies of themselves past, when they come suddenly to remembrance, except they bring with them any present dishonour. (Emphasis in the original.)

There is an accompanying sense of "superiority" whereby the joker/audience sees him or herself as being better or having moved away from the position/state within which the individual being joked about still exists. The third Relief theory of humour is primarily interested in the cathartic effect of laughter which is the sense of relief that comes after one has gone through a bout of mirth. It is the humour "released by 'excess' nervous energy which actually masks other motives and/or desires" (McCreaddie \& Wiggins 2008: 585). Almost all forms of humour elicit relief in the audience, meaning that just every form of humour can be categorised as belonging to this category.

Sometimes, there is a level of incongruity within jokes that have instances of a feeling of superiority, an indication that these forms of humour theory mostly work symbiotically. Where incongruity is present in the juxtaposition of two or more unbalanced conditions, my coinage, incongruous liaison, underscores the interplay of disproportionate abjects (objects and subjects) within jokes. It specifically portrays the situation of stand-up routines being deliberately fashioned with tools, situations, and personalities that exhibit humour-bearing inequities, inequalities, imbalance-incongruity essentially. The term therefore portrays the comparison of sundry verbalised and embodied mis/representations comedians deploy during performances which often materialise as satire, parody, outright insult, farce, and perhaps, political incorrectness. Thus, the liaisons between joke materials within the ephemeral cauldron-like depository comedians use are basically incongruous. It is noteworthy that without the stand-up artist's arrangement and embodied accompaniments, mirth may not be achieved to its fullest.

Furthermore, the uniqueness of Nigerian stand-up comedy transcends the bequests of similar pre-colonial forms of humour enactments mentioned above; obvious pillaging of American-style of stage humour; and its nomenclature. Evolving in the 1990s, the parturition of this art form in the country at that time exemplifies the transcendence of popular tradition over more conventional ones; the same period oversaw the emergence of the video film industry, popularly known as Nollywood. Together with the video film, Nigerian stand-up comedy is now one of the most patronised entertainment performances on the continent. Its exponential spread has been aided by new media-social media, the internet, and cable TV. Also, because it shares some of Nollywood video film distribution channels, it is also being distributed on VCDs and DVDs. It is instructive also that stand-up comedy thrives in Nigeria which has witnessed a decline in live theatre practice from the early 1980s till date, even when some of the reasons adduced for the low patronage theatre at the time-low remuneration for practitioners, unsafe streets at nights, paucity of funds, etc.- have not abated. One reason for this is that unlike theatre, stand-up comedy is a more contemporaneous art where the performer talks about current issues without having to go through the rigors of first doing a 
script, sourcing for funds to stage the script, casting, hiring venue, and even rehearsing. Hence, with the dearth of capital especially for investments in the arts, survivalist arts like stand-up comedy and video films become preferable mainly due to their predisposition to minimal financial requirements.

Commenting on the simultaneous decline of live theatre and rise of stand-up comedy in Nigeria, Onyerionwu (2007) observes the following:

For those who have been disheartened by the continuous decline of the Nigerian theatre tradition, the advent of an avant-garde alternative in the emergent stand-up comedy culture has hugely compensated for a truly sad loss. This feeling of loss is completely understandable ... But today as we have come to see, the only artistic medium that has undisputedly inherited [... the] laudable responsibilities of the theatre tradition is stand-up comedy. It is perhaps to the credit of the many characteristics which both genres share that an overlap-free transition has been guaranteed. First, like the core dramatic theatre, stand-up comedy is essentially a stage art.

One agrees with this position that stand-up comedy is a theatre form, but it does not follow that it has emerged as a replacement. It is rather a complimentary form to theatre and to other ones that it draws its eclectic nature from. Primarily, being that its recorded versions are distributed in VCD/DVD formats, it makes use of media art and video technology. As such, these electronic formats can be evaluated for filmic attributes. Also, music artists often perform live on stage in between the performances of jokes, thereby Nigerian stand-up comedy links itself with the highly successful popular music tradition. Thirdly, alongside the rendition of jokes, Nigerian stand-up comedy shares some theatrical elements with theatre such as costume and make-up, lighting, scene design, acoustics, and even audience management. Finally, elements of oral tradition, especially storytelling, are identifiable in the acts of some Nigerian comedians. This is an indication of stand-up's roots in the indigenous comedic performances some of which have been mentioned previously. It then follows that, for its syncretic nature, Nigerian stand-up comedy defies easy categorisation. Also, its multimedia nature and myriad borrowings from different cultures is another instance of incongruous liaison.

\section{Interrogating humour themes in Nigerian stand-up}

Nigerian stand-up art has taken a tortuous and rigorous path to success. Previously, comedians were treated with disdain and were merely taken as secondary masters of ceremony without much earnings. In more recent times, with support from multinational and local firms in telecommunication, banking and other services, stand-up events are now well bankrolled and comedians themselves are also being taken care of handsomely. From just one event in the 1990s, other stand-up shows have emerged with many performers making their debut and turning out successful eventually. The four comedians that are of interest here are selected purposively because together they represent the wide range of individual performance mechanics existing on the Nigerian stand-up stage. I Go Dye, born Francis Agodan, is from Warri, a city in the nation's restive oil-rich Niger-Delta region. AY (Ayo Makun) is Yorubaspeaking but was raised at Warri too. The rest, Basket Mouth (Bright Okpocha) and Klint da' 
Drunk (Ahamefula Igwemba), are both Igbo but while the former grew up in Ajegunle, ${ }^{2}$ a suburb of Lagos, Klint spent most of his childhood in Enugu. One unifying element most of them share, regarding their growing up days, is the experience of poverty both in Ajegunle and Warri as well as other sites where Nigerians suffer amidst plenty which is in the hands of a few. Perhaps it is for their experiences of deprivation that the theme of poverty and hunger is recurrent on the country's stand-up stage. Talking about growing up, for instance, AY says:

[It was] rough, pretty rough. Not too rough from the beginning because I was a rich kid [...] but subsequently from taking cars to school, I started trekking to school. It is easier for you to be poor and later rich than to be rich and then poor. [...] It got to a stage I had to fend for myself. I was a wash man and a scavenger. Even when I was in the university I sought for models and got commissions from them.

(Elugbaju 2010)

He also spent extra three years at the University because he had no funds to pay his fees (Makun 2007). I Go Dye, for his part, dreads poverty because it makes an individual so worthless that people hardly notice him/her(Williams, Nite of a Thousand 13); and elsewhere, he says a person's hair can turn from black to brown because of poverty which can make it impossible for one to afford a decent bathing soap. He does not say here whether he is the one that used cheap soaps to bath, but elsewhere he claims that he has experienced poverty firsthand (Williams, Nite of a Thousand 16). The rest often make claims of affinity with poverty while growing up. Basket Mouth said how poor his family was when he was young and how difficult it was for him to eat regularly when he was in the university, to emphasise the huge gap between privileged and non-privileged Nigerians as he drew the attention of his interviewers to the disparity in housing within Lagos (Anon 2015). His characteristic way of underscoring the severity of his pauper experience is to state within some of his stage events that his family was so poor that even the poor called them "poor". Klint is one of the few comedians who appear in dishevelled shrunken state. It is perhaps his own way of maintaining an identification with the majority poor population of his country.

Identification with poverty is one tool that comedians use to create the kind of friendliness they need with the audience in order to have a perfect atmosphere for humour exchange. This affinity is necessary and basic for the kind of environment that makes suspension of offence possible, because it is only friends that can trade jokes without real fear of violence. There are other ways this is achieved such as talking directly to members of the audience and allowing more performer-audience interaction that makes people feel that they are part of the humourist's act. Klint is adept at handling heckles and is known to have been using a lot of this technique. I Go Dye intersperses his acts with shouts of "Area!", something that has become a kind of trademark for most comedians from Warri. ${ }^{3}$ AY and Basket Mouth are quite spontaneous and adept at adapting to individual audiences and situations. However, in the absence of obvious censoring legislations, each of these comedians are self-censored while rendering their jokes. Moreover, the levels of political incorrectness and insult in their performances differ.

\footnotetext{
${ }^{2}$ Warri and Ajegunle share a lot of similarities. It is instructive that together, Warri and Ajegunle, have produced more comedians in Nigeria than any other city. One common feature to these sites is their cosmopolitan outlook, being that their inhabitants are from different ethnic backgrounds. In Warri, it is Itsekiri, Urhobo, and Ijaw, while Ajegunle boasts of having a sizeable representation from all ethnicities in the country. Due to their mix-culture residents, Pidgin English, which is also the lingua franca of Nigeria's stand-up art, is the primary language of communication.

${ }^{3}$ It is usual for one Warri person to call another by this salutation. It indicates that the person being hailed is a true child of the soil; an authentic member of the Area (locality).
} 
Political correctness refers to being conscious of actions or words that could offend certain groups of people who could be in the minority or disadvantaged and making sure that they are not used in one's conversations, both verbal and written. On the Nigerian stand-up stage, there are instances of political incorrectness possibly because the public is yet to start holding performers responsible for their utterances. Instances of politically incorrect jokes that these comedians tell border on ethnicity, gender, religion and even sexuality. I Go Dye, for instance, builds joke narratives around the presupposition that Nigerian girls do not care about anything else other than their men's money and end up calling them "aristos". ${ }^{4}$ This is an assumption that even Basket Mouth also has, an unwarranted generalisation about young women, sex and their relationships with the opposite sex. There is ethnic stereotyping also. For the major tribes of the country, the Hausa-Fulani is often not very intelligent suya ${ }^{5}$ seller or cattle tender; while the cowardly but tough-talking and arrogant Yoruba man contrasts the money-loving, greedy Igbo man. Negative jokes about same-sex relations have also featured especially in the performances of AY and Basket Mouth.

In a country like Nigeria, with a preponderance of socio-political drama, there is hardly any scarcity of materials for comedy within its political arena. Basket Mouth, talking about the bad economy, once said: "We jus' get money, everybody jus' de chop!" [We have money and everyone (meaning the politicians) are just taking as much as they desire] to typify the way politicians brazenly engage in corrupt practices. He takes a swipe on the non-performance of a former governor of Lagos State, on the Federal government that held onto the state government's fund at the time and wondering why the government chose to deprive the citizens of the amenities that such allocation could provide (Okpocha 2007; Makun 2008; Williams, Nite of a Thousand 13). AY, on his part, talks about a Nigerian wife-beater who leaves a trail back home to travel to the US, where he meets and marries an American woman. Before long, he beats her as he characteristically did to other women back home, but unlike his Nigerian partners, the American pulls out her pistol on him. Scared for his life, he runs into the bathroom and barricades himself there. The wife then plants herself in front of the bathroom door and calls to him "Fashola" (governor of Lagos State at that time), and with the sweetest imitation of a lady's voice he adds: "Come out and let's settle this once and for all". The man, in a bid to save himself, calls the US Immigration from the bathroom, to come and deport him to Nigeria immediately (Makun 2008). The punchline, which got the audience reeling with laughter and which was delivered on this occasion very accurately, was "Fashola". The comedy here lies in this improbable juxtaposition: putting up one of the most performing governors of Lagos State Fashola as a wife-beater. One does not rule out the possibility of an allusion to the manner agencies of government were preying on the citizens of the state to generate more revenue for the government. Here, AY simply gives a joke narrative, sparingly using a politician's name, and without making any explicit political statement, leads the audience into making their own associations and creating their individual laughters which gives him the artistic collective his arts craves.

Another classic is Klint's parody of President Obasanjo where he berates Nigerians for saying that "our president" is ugly; telling them to stop making such remarks because the president is a "film star". ${ }^{6}$ He pauses for effect, as the audience tries to understand what is

\footnotetext{
${ }^{4}$ A common name for semi-commercial sex workers in Nigeria; especially young University students who follow mostly rich men and offer sex for money. The term is shortened from "aristocrat", a word that the "aristo" coinage seems to have jettisoned.

${ }^{5}$ Grilled cattle meat mostly held together with a stick and eaten with pepper, onions and assorted vegetables.

${ }^{6}$ President Obasanjo (civilian president, 1999-2007) could well be the Nigerian leader that has been targeted more than any other leader in stand-up jokes. He was kindly disposed to comedians during his rule and is known to have told his own share of jokes about comedians themselves. Humourists often create comedies from his facial looks, speech mannerism and pot-belly as well as his tight-fisted, stingy nature.
} 
coming next. He then adds: "Do you know the film, King Kong? [pause] Who acted the monkey?" The audience goes wild with laughter. His rejoinder to this, given with a very straight face, is: "What do you expect? He looks like the condition of the nation" (Williams, Nite of a Thousand 4). With these last statements, Klint boldly steps into Bakhtin's carnivalesque-boldly telling the people that the president is responsible for their woes and sundry difficulties. The audience laughs, not at their predicaments, but at Klint's jocular treachery. He first pretends that he is not going to talk about the president's facial uncomeliness like most comedians have been doing; but ends up doing just that more gruesomely by likening him to the not-very-handsome filmic personality, King Kong. For his part, I Go Dye rarely ridicules politicians by name, but often talks about poverty and how having money makes people relevant in the society, so they can dine with presidents (Williams, Nite of a Thousand 11). But he does not miss this opportunity to take a swipe on a former president's now, late wife, Stella Obasanjo:

If you look for Naija now, dem don de bound things. Dem bound Belgium cars, turkey, okirika ... I wonder how poor people go de take wear cloth. Na so, one night Stella go meet de president, tell am say: "Oby ${ }^{7}$ dis one wey you don de bound everything, no bound pancake o!" [Audience laughs explosively] Na joke I dey o! (Williams, Nite of a Thousand 4)

[When you look at Nigeria today, one observes that there is ban on the import of some goods. They have banned importation of cars, frozen turkey, second-hand clothes ... I wonder how poor people can afford new dresses. It's because of this that Stella met the president and said: "Oby, now that you are banning everything, do not ban 'pancake' too!" (...) I am only joking!]

This joke has a few allusions chief of which is that Stella Obasanjo is known to be a heavy user of facial concealers known as pancake in Nigeria.

Religion is another recurrent theme. It is a very sensitive issue because it has caused innumerable violent and deadly conflicts especially between the north and the south, which have been erroneously dubbed Muslim north and Christian south by the media. ${ }^{8}$ Apart from the deadly riots of 2002 and 2005 sparked by the botched hosting of the Miss World beauty contest in Nigeria, and the Danish newspaper Jyllands-Posten's editorial cartoons of Prophet Muhammad, Nigeria's ethno-religious crises have mostly had other root causes that are mostly political rather than related to intolerance for any form of arts or entertainment. Most Nigerian stand-up performers are from the south and are mostly of the Christian faith. The ones under study here have kept their religious jokes mostly to their own creed, in the main, ridiculing the over-zealousness of church members in contributing to their pastors' flamboyant lifestyle while remaining in poverty themselves. I Go Dye, for instance, once wondered why contemporary pastors claim, at every turn, that God speaks to them whereas in the Bible Moses had to fast for seven days before he could hear God. He continues to say that a pastor can come out of his room after a short while to claim that God spoke to him, all in a bid to swindle people. He then throws a puzzle: "Bible talk say 'greater work than I did, will you do;' Moses divide Red Sea, which Nigerian pastor don divide even gutter?" [The Bible says, "Greater work than I did, will you do;" Moses parted the Red Sea which Nigerian pastor has parted gutter?] (Williams, Nite of a Thousand 4). Elsewhere he says that pastors ask church members to "Give offering that will challenge God", and then wonders "How somebody go

\footnotetext{
${ }^{7}$ Supposedly a shortened pet-name for Obasanjo, developed by Nigerian comedians; but "Oby" is funny because it alludes to an Igbo girl's pet name derived from "Obiageli."

${ }^{8}$ This is an erroneous supposition because apart from the very sizeable Muslim population in the south west, there exists also, many Christians, not only in the Middle Belt (part of northern Nigeria) but also in the far north in places like Gombe, Borno, Kebbi, Adamawa, and Bauchi. Incidentally, successive Nigerian governments have also barred the collection of population census based on religion.
} 
give offering wey fit challenge God?" [How can someone give an offering that can challenge God?], especially when they still teach that God owns the whole universe. He says that he is only concerned about African traditional priests who have refused to "upgrade" to the use of tablets, social media, and the internet (Williams, Nite of a Thousand 20), like their fellow priests in the Pentecostal churches.

Others create religious humour also, especially AY whose stock-in-trade routine it is to imitate Nigerian clergymen like his own pastor, Chris Okotie. His next favourite is Chris Oyakhilome, popular gaudy Nigerian pastor known all over Africa for his televised healing crusades and the accompanying display of miracles. His true-to-life depictions of these persons earned him a lot of popularity very early in his profession, but now he prefers the character of an Aladura ${ }^{9}$ prophet who, on stage, dispenses unsolicited but very hilarious prophecies on specific members of the audience and, on social media skits, is seen contending with the ever-present and altering temptations of the "daughters of Eve" who are adamant on bringing down the prophet's "ministry". Oftentimes, he has an interpreter who renders his prophecies into simpler but comic English (if he is performing to a foreign audience, abroad or elsewhere), or misinterprets in Yoruba (if he is in Lagos and environs). This acolyte prophet of his is Elenu, another Nigerian comedian, who elicits laughter with his jocular misinterpretations and farcical embodied actions. AY uses this persona to address issues within the society, raising them as prophecies but without failing to amuse the audience with burlesque, parody, satire, and the likes. Where Basket Mouth talks about pastors and greed too, his mention of the religious crises that have rocked the north central city of Kaduna repeatedly during one of the few shows held there, is instructive of how comedians mention taboo subjects quite surreptitiously without delving deeply into volatile terrains (Williams, Nite of a Thousand 13). One thing that stands out here is that these comedians obviously avoid crisesladen subjects by staying within their own religious terrains in order not to stray into other faiths that they do not know much about. It is such forays into subjects that one is not very familiar with that could incite and provoke violence.

Next to religion, another flashpoint theme in the Nigerian society, is ethnicity. Ethnicbased humour is mostly derived from imitations of mother-tongue interferences in English diction of the different language groups. The Hausa swaps letter " $p$ " for " $f$ " and vice versa in speech. Hence, "field" becomes "pield" while "president" is pronounced "frezident." This also happens with letters "b" and "v", for this group, where "very" becomes "bery", to mention a few. The Igbo, Ibibio, Anang and some other groups characteristically interchange letters " $r$ " and " 1 ". The city of "London" becomes "Rondon," and "Rice" is rendered "Lice", for instance. The Yoruba prefixes " $\mathrm{h}$ " in pronouncing words beginning with vowels and omits same where it precedes a vowel. For example, "eye" becomes "heye" (pronounced "high"), while others like "hand" and "hope" are pronounced "and" and "ope". Also, there exists an inexhaustible array of speech patterns and behavioural labels for other ethnicities, too. I Go Dye, for instance, jocularly said that in Calabar churches, it is difficult to differentiate between the preacher and the interpreter because they speak the English language with the same sing-song inflections that the local languages are spoken. ${ }^{10}$ Afterwards, he adds that when his friend from Calabar keyed his native names into the computer, it simply showed an error message (Williams, Nite of a Thousand 1). These jokes ridicule the speech pattern of people from parts of Cross River and Akwa Ibom states of south eastern Nigeria whose characteristic soft voices,

\footnotetext{
9 A Christian sect founded in Nigeria around the 1920s, which mixes their worship with African religious practices, fused with prophecies and seeing of visions. They are also referred to as white-garment church because the members wear white gowns and often go bare-footed. Wole Soyinka's Brother Jero, created in his eponymous drama of the 1960s, is a dramatic archetype of an Aladura prophet.

${ }^{10}$ Calabar is a major port city in the south of Nigeria. It is made up of different ethnicities but is used mostly, sometimes derogatorily, to refer to people from the present-day Akwa Ibom and Cross River states.
} 
fast-paced speech pattern and fixed sing-song rhythm, often sound as if the speaker is singing, so much so that when someone with such accent says his/her name, it is often long and mostly sounds like a poem or a short song.

To take the issue of ethnic behaviour labelling further, Basket Mouth says that if Osama bin Laden had come to Nigeria, he would not have succeeded in recruiting any Igbo man for suicide bombing because his simple answer, in a thick Igbo accent, will be: "Nna, give my family the bomb and give me the money" (Williams, Nite of a Thousand 13). ${ }^{11}$ This joke is predicated on the supposition that the Igbo person can forfeit anything for money. In the same vein, Klint tells of how an Igbo man was accosted by armed robbers who asked him to make a choice between parting with his possessions and being intravenously injected with the HIV virus. He takes the second option because, under the pretext of taking a moment to urinate, he quickly puts a condom on in a bid to stop himself from being infected (Williams, Nite of a Thousand 13). Here, foolery has clouded the man's mind to the point of thinking that wearing a condom means he cannot be infected intravenously. Two things stand out: ignorance and greed, two characteristics that have somehow been plastered on the Igbo. It is instructive that the duo of Basket Mouth and Klint are of Igbo origin. They are not alone in the vilification of their people. AY and I Go Dye also talk derogatorily about Warri people, especially their stereotypical predisposition to crime and violence. But there is another aspect of the inhabitants of this city which also comes up in stand-up jokes: the ability not to be intimidated, no matter where they are or what the situation is. There is even a saying that often accompanies any mention of the Warri's person's indefatigability - "Warri man no de carry last" [Nobody from Warri comes last in any endeavour].

One more interesting theme is that of heterosexual relationships. Basket Mouth said on stage many years back that he is not planning to get married "in the next twenty years" because "marriage is like having DSTV subscription to many TV channels, but you can only watch one all the time". ${ }^{12}$ His marriage is now well over five years old. Essentially, the comparison between marriage and being stuck with one television channel when it is possible to access others, is an allusion to the fact that while a television channel may be interesting at a time, there are periods that it could be monotonously boring just like marriage can be sometimes. Elsewhere, he states that "Women are ten times smarter than men". He then goes on to prove it by talking about Adam and Eve, asserting that since the length of time between when Eve ate the fruit and the time she gave it to Adam is not stated in the Bible, it could have been a couple of years or less. This implies that she could have been watching Adam running around the Garden, naked. His claim is that Eve must have taken time to be amused by Adam's ignorance of his own nakedness before "helping him" out of it. What is important in this very rendition is the manner which he says a whole lot with a mix of non-verbal facial expressions and hanging statements.

All the comedians under study here are talk about heterosexual relationships and how they affect the society, but the prayers of I Go Dye and Basket Mouth sum up the tenor of frustration that young men feel when losing their girlfriends and potential wives to richer and older men. I Go Dye prays with all seriousness:

All 'aristos' who will not let us meet our future wives, may their cars break down on top Third Mainland Bridge ... Holy Ghost...! (Williams, Nite of a Thousand 3)

\footnotetext{
${ }^{11}$ Igbo word for "father" but also used for every male. Here specifically used to mean "my brother" or "my friend".

${ }^{12}$ A multi-channel pay-tv cable channel managed by the South African company Multichoice.
} 
And the audience shouts in response: "Fire!" On another occasion, Basket Mouth makes the same prayer with more fervour:

God go punish all de 'aristos' in Jesus' name! [...] Una don marry una wives come de confuse our future wives. We go buy dem recharge card, una go buy dem phone. We go give dem moni for cab, una go buy dem car. (Williams, Nite of a Thousand 12)

[God will punish all the 'aristos' in Jesus' name! (...) You have married your own wives and are now confusing our future wives. When we buy phone credits for them, you buy phones for them. When we give them money for taxi, you buy cars for them. Who will the girl listen to then?]

As stated earlier, these prayers are popular with audiences because they encapsulate the frustrations of struggling people who are at a disadvantage because they are contending with a more privileged class. It is not just about girls but about every other endeavour there is, because the country is full of folks with deep pockets who, at every turn, muddle the waters with their greed for others who are just trying to get by with minimal sustenance. The way these comedians present heterosexual relations here exemplify their fondness for portraying normal situations in a grotesque manner with a view to exploring them humorously. With the prayer above, for instance, Basket Mouth aligns himself with many members of the audience (who may have also had experiences of being dispossessed of many things by richer folks), on the one hand, and presents the power of the rich to take as absurd, on the other.

\section{Tools for self-censorship in Nigerian stand-up}

Despite all that has been said about politically incorrect jokes within Nigerian stand-up, it is pertinent to note that the comedians themselves are finding ways of cleaning up their acts and making them more accessible to more individuals. A good indication of this is given by Klint in his performance at the Easter 2016 AY Live event at Lagos. His initial comments on stage as he walks in is to tell the audience that making people laugh through jokes is not easy at all. He complains that while backstage, they were admonished by the organisers to clean up their jokes and dispense of all allusions to the female genitalia, for instance, because the multinationals sponsoring their events are really complaining. He then asks the audience whether it is not the same companies that complain about lewdness in stand-up comedy that sponsor Nigerian singers who talk about nothing but a woman's breasts, waist, and sex organ: "Why are they complaining about us?", he muses. Klint's frustration is evident. He goes on to choose a few popular Nigerian songs to show how sensual their lyrics are and wonders why a different set of rules is being created for stand-up artists. He even tells the audience, jocularly though, that the comedian, Elenu, who performed before him, had been reduced to singing nursery rhymes in the name of amusement due to all the restrictions that are being erected (Makun 2007). Klint's jocular remarks exemplifies how extrinsic limitations can shrink comic materials and the consequent difficulties practitioners face.

To make people laugh, the comedian must necessarily offend. What happens is that within a joke situation, framed by its liminal, temporal nature, there is an unwritten contract which concurrently absolves the comedian of slander and allows the spectator not to pick offence. Without this convention, the joke is no joke and is then susceptible to bring offence. Comedians deploy forms of self-censorship in moderating their own jokes because they are conversant with how restrictive external impositions could be. Also, spectators' withholding of laughter is an additional way of censoring performances. This is so because stand-up comedy depends heavily on immediate responses from the audience and the humourist, as much as possible, gauges individual reception and rejection of specific jokes to determine how 
succeeding narratives will go. Hence, the initial part of self-censorship is the consciousness of the spectator's acceptance and/or rejection of specific jokes because, as Limon (2000: 11) posits, group response in stand-up situations is "single-minded and unimpeachable".

The place of the performance is another salient tool for self-censorship. Within stand-up performances, place "can mean both the location and the stage (whether elevated or not) from which the comedian speaks to the audience" (Nwankwọ 2014: 1561). One often makes a distinction between location and environment, designating the first as the site of the routine, and the second as the ambience. In Basket Mouth's subtle mention of religious crises while performing in Kaduna, in northern Nigeria, is a good example of how place affects the manner of presentation. Place therefore does not only inform the selection of themes but also the way they are broached. It thus, in no small measure, constrains performers to moderate their presentations in deference to the sensitivities of a greater number of the spectators. Since friendliness is a basic requirement for joke creation and reception, it would be foolhardy for any performer to antagonise the members of the audience by presenting sensitive subjects in overtly offensive ways.

Furthermore, comedians deploy a very helpful device which one might call "identification with the audience" to stem off unfriendliness. Performers use this tool to form an alliance with the audience so that the jokes do not come out as a "me-against-s/he" or "we-against-them" kind of narrative, where they ridicule their audiences as outsiders; but as a "we-and-us" presentation which puts the humourist in the mix of the caricature itself, as an insider, in oneness with the audience. Hence, whenever I Go Dye shouts "Area!" and adds "Warri people dey here?" [Do we have people from Warri here?] in a place as far-flung as the O2 Arena in London, he is not looking to find his relations, but to form a convivial, if not filial, community with the audience, the canvas against which he, like a painter, begins to etch out his jokes - his art. To the preceding example, we can also add the innumerable instances of identification with poverty wherein a good number of comedians have claimed having lived in penury themselves. In more ways than one, through this medium they inform their audiences that despite their present opulent living, they have a past that is like the average Nigerian's, thereby creating a certain level of closeness with their spectators.

\section{Conclusion}

In this essay, through a study of the possible pre-colonial borrowings of stand-up comedy in Nigeria, I presented the specific challenges of humour-generation confronting contemporary artists. Chief among these is the issue of instigating laughter through causation of offence against the backdrop of prevailing calls for more intense censorship of jokes. The concern here is that for an art form that needs to be constantly fresh in order to continue making its mark, over insistence on political correctness and perhaps an imposition of legislations, will drastically shrink its boundaries, thereby depopulating the corpus, as well as, limiting the liaisons of the tools stage humourists deploy. Comedians should, however, imbibe the habit of self-censorship in order to ensure that their art is held back from taking a foray into the arena of violence and unacceptability.

\section{References}

Anon. (2015). 'Basketmouth: Trash talking' [online video]. August 24. Aljazeera. https://www.aljazeera.com/programmes/my-nigeria/2015/08/basketmouth-trash-talking$\underline{150817125117101 . \mathrm{html}}$

Ajaye, F. (2002). Comic Insights: The Art of Stand-up Comedy. Beverly Hills: Silman-James. 
Bakhtin, M. (1968). Rabelais and His World. Trans. Helene Iswolsky. Bloomington: Indiana University Press.

Elugbaju, F. (2010). 'I am a proud product of the street'. July 11. Nigerian Compass. Retrieved Dec. 9, 2011 from https://www.nigeriamusicmovement.com/nigerian-musicnigeria-i-am-a-proud-product-of-the-street

Freud, S. (2002). The Joke and Its Relation to the Unconscious. Trans. Joyce Crick. London: Penguin Books.

Furniss, G. (1996). Poetry, Prose and Popular Culture in Hausa. Edinburgh: Edinburgh University Press.

Grainger, R. (2010). The Uses of Chaos. Oxford: Peter Lang.

Hazlitt, W. (1819). Lectures on the English Comic Writers. London: Taylor \& Hessey.

Kofoworola, K. G. (2007). 'The court jester in Nigerian drama', in Robb, D. (ed.), Clowns, Fools and Picaros: Popular Forms in Theatre, Fiction and Film. Amsterdam and New York: Rodopi, pp. 101-114.

Lawal, B. (1996). The Gelede Spectacle: Arts, Gender, and Social Harmony in an African Culture. Seattle: University of Washington Press.

Limon, J. (2000). Stand-up Comedy in Theory, or, Abjection in America. Durham, NC: Duke University Press.

Makun, A. (2007). AY Live Volume 2 [VCD]. Lagos: Obaino Music.

Makun, A. (2008). AY Live Volume 3 [VCD]. Lagos: Obaino Music.

McCreaddie, M., \& Wiggins, S. (2008). 'The purpose and function of humour in health, health care and nursing: A narrative review', Journal of Advanced Nursing 61 (6), pp. 584-595. doi:10.1111/j.1365-2648.2007.04548.x.

Meek, C. K. (1937). Law and Authority in a Nigerian Tribe. London: Oxford University Press.

Monro, D. H. (1951). Argument of Laughter. Melbourne: Melbourne University Press.

Nilsen, D. L. F. (2001). 'Book review', Humour: International Journal of Humour Research 14 (4) November, pp. 424-430.

Nwachukwu-Agbada, J. O. J. (2004). 'Igbo humour in the novels of Chinua Achebe' in Emenyonu, E. \& Uko I. I. (eds.), Emerging Perspectives on Chinua Achebe Vol. II: Isinka, The Artistic Purpose: Chinua Achebe and the Theory of African Literature, New Jersey: Africa World Press, pp. 151-167.

Nwachukwu-Agbada, J. O. J. (2007). 'Ezenwa-Ohaeto: poet of the njakiri genre', in Matzke, C., Raji-Oyelade, A. \& Davis, G. V. (eds.) Matatu - Journal for African Culture and Society - of Minstrelsy and Masks: The Legacy of Ezenwa-Ohaeto in Nigerian Writing, Amsterdam and New York: Rodopi, pp. 153-177.

Nwankwọ, I. E. (2014). 'Taking offence with no offence: Relevance of time and place/space within Nigeria's stand-up comedy', ECAS 2013: 5th European Conference on African Studies - African Dynamics in a Multipolar World. Lisbon: Centro de Estudos Internacionais do Instituto Universitário de Lisboa (ISCTE-IUL), pp. 1549-1570.

Obafemi, O. (1996). Contemporary Nigerian Theatre: Cultural Heritage and Social Vision. Bayreuth: African Studies Series.

Okpocha, B. (2007). Basket Mouth Uncensored Volume 2 [VCD]. Lagos: CN Media.

Onyerionwu, E. (2007). 'Stand-up comedy and dead-end of theatre tradition' May 27, The Vanguard. Retrieved December 16, 2018, from https://allafrica.com/stories/201005170666.html

Radcliffe-Brown, A. (1940). 'On joking relationships', Africa: Journal of the International African Institute 13 (3) July, pp. 195-210.

Raskin, V. (1985). Semantic Mechanisms of Humour. Dordrecht: D. Reidel.

Rutter, J. (1997). 'Stand-up as interaction: Performance and audience in comedy venues', PhD. Thesis. Dept. of Sociology. University of Salford, pp. xi+387. 
Tafoya, E. (2009). The Legacy of the Wisecrack: Stand-up Comedy as the Great American Literary Form. Boca Raton, FL: BrownWalker.

Williams, O. (2002). Nite of a Thousand Laughs Volume 1 [VCD]. Lagos: Obaino Music. Williams, O. (2004). Nite of a Thousand Laughs Volume 4 [VCD]. Lagos: Obaino Music. Williams, O. (ND). Nite of a Thousand Laughs Volume 8 [VCD]. Lagos: Obaino Music. Williams, O. (2007). Nite of a Thousand Laughs Volume 11 [VCD]. Lagos: Obaino Music. Williams, O. (ND). Nite of a Thousand Laughs Volume 12 [VCD]. Lagos: Obaino Music. Williams, O. (ND). Nite of a Thousand Laughs Volume 13 [VCD]. Lagos: Obaino Music. Williams, O. (2008). Nite of a Thousand Laughs Volume 15 [VCD]. Lagos: Obaino Music. Williams, O. (ND). Nite of a Thousand Laughs Volume 16 [VCD]. Lagos: Obaino Music. Williams, O. (ND). Nite of a Thousand Laughs Volume 20 [VCD]. Lagos: Obaino Music. 